\author{
Review Article
}

\title{
Solid Catalysts and Their Application in Biodiesel Production
}

\author{
Ramli Mat*, Rubyatul A. Samsudin, Mahadhir Mohamed, Anwar Johari \\ Department of Chemical Engineering, Faculty of Chemical Engineering, Universiti Teknologi Malaysia \\ 81310 UTM, Skudai, Johor
}

Received: 6th April 2012; Revised: 24th October 2012; Accepted: 24th October 2012

\begin{abstract}
The reduction of oil resources and increasing petroleum price has led to the search for alternative fuel from renewable resources such as biodiesel. Currently biodiesel is produced from vegetable oil using liquid catalysts. Replacement of liquid catalysts with solid catalysts would greatly solve the problems associated with expensive separation methods and corrosion problems, yielding to a cleaner product and greatly decreasing the cost of biodiesel production. In this paper, the development of solid catalysts and its catalytic activity are reviewed. Solid catalysts are able to perform transesterification and esterification reactions simultaneously and able to convert low quality oils with high amount of free fatty acids. The parameters that affect the production of biodiesel are discussed in this paper. (C) 2012 BCREC UNDIP. All rights reserved
\end{abstract}

Keywords: Biodiesel; Heterogeneous Catalyst; Solid Acid; Transesterification; Esterification

How to Cite: R. Mat, R.A. Samsudin, M. Mohamed, A. Johari. (2012). Solid Catalysts and Their Application in Biodiesel Production. Bulletin of Chemical Reaction Engineering \& Catalysis, 7(2): 142-149. (Article Inpress). (doi:10.9767/bcrec.7.2.3047.142-149)

Permalink/DOI: http://dx.doi.org/10.9767/bcrec.7.2.3047.142-149

\section{Introduction}

The world's crude oil reserve is fast declining due to demand in electricity generation and fuel oil in energy intensive sectors such as petrochemical and transportation. The consumption of transportation fuels is continuously increasing with large majority of it is derived from nonrenewable fossil fuel. The drawback of using fossil fuels is well documented in various communications in media and scientific journals as a source of environmental problems particularly when dealing with the quality of the exhaust gases emitted from their respective combustion.
Such great concern is directed to the generation of the green-house gases such as $\mathrm{CO}_{\mathrm{x}}, \mathrm{SO}_{\mathrm{x}}$ and $\mathrm{NO}_{\mathrm{x}}$. These pollutant gases are hazardous to human health and some are of carcinogenic in nature. Efforts are made by researchers, scientists and environmentalists to spearhead the use of alternative fuels which are non-pollutant, environmental friendly as well as renewable in nature. Biodiesel has been identified as one of the most promising sources of alternative fuels. Transesterification of triglycerides (TGs) with methanol has been known as the central reaction in the synthesis of biodiesel from oils and fats that

\footnotetext{
* Corresponding Author. E-mail: ramli@cheme.utm.my (R. Mat)

Tel: +607-5535507, Fax: +607-5588166
} 
produces chemical compounds known as fatty acid methyl ester (biodiesel).

Most of the commercial production of biodiesel worldwide uses homogeneous base catalysts, which are corrosive and non-reusable and produces waste that needs to be neutralized, hence, increasing the overall costs and leads to an environmental concerns. Homogeneous base catalyst (e.g., $\mathrm{NaOH}$ ) is most commonly used process to produce biodiesel by transesterification of triglyceride and methanol.

Solid catalysts have found widespread application in the catalysis field and belong to the group of new catalytic material which has greatly developed in recent years. However, research activities using solid catalysts for biodiesel synthesis has been limited due to low expectations about reaction rates and probable undesired side reactions. Table 1 shows comparison of homogenous and heterogeneously catalyzed transesterification heterogeneous acid catalyst [1].The advantage of using homogeneous catalyst especially base catalyst is cheaper catalyst cost. However, it requires refined oils containing not more than $0.5 \%$ of free fatty acids (FFAs) and anhydrous conditions. Therefore, the production cost of biodiesel is higher if refined oil is used instead of low quality of feedstock. The main advantage of a heterogeneous catalyst is that the catalyst is easily separated from the reactants and products. Reduction of the biodiesel production cost can be achieved if heterogeneous catalyst is used. Heterogeneous catalyst offers easier production process, improve product quality and also reduce corrosion and toxicity problems. Furthermore, it

Table 1. Comparison of homogenous and heterogeneously catalyzed transesterification [1]

\begin{tabular}{|c|c|c|}
\hline Factors & $\begin{array}{c}\text { Homogeneous } \\
\text { Catalysis }\end{array}$ & $\begin{array}{c}\text { Heterogeneous } \\
\text { Catalysis }\end{array}$ \\
\hline $\begin{array}{l}\text { Reaction } \\
\text { Rate }\end{array}$ & $\begin{array}{l}\text { Fast and high } \\
\text { conversion }\end{array}$ & Moderate conversion \\
\hline $\begin{array}{l}\text { After treat- } \\
\text { ment }\end{array}$ & $\begin{array}{l}\text { Catalyst cannot } \\
\text { be recovered, } \\
\text { must be neutral- } \\
\text { ized leading to } \\
\text { waste chemical } \\
\text { production }\end{array}$ & Can be recovered \\
\hline $\begin{array}{l}\text { Processing } \\
\text { methodology }\end{array}$ & $\begin{array}{l}\text { Limited use of } \\
\text { continuous meth- } \\
\text { odology }\end{array}$ & $\begin{array}{l}\text { Continuous fix bed } \\
\text { operation is possible }\end{array}$ \\
\hline $\begin{array}{l}\text { Presence of } \\
\text { water/free } \\
\text { fatty acids }\end{array}$ & Sensitive & Not sensitive \\
\hline $\begin{array}{l}\text { Catalyst } \\
\text { reuse }\end{array}$ & Not possible & Possible \\
\hline Cost & $\begin{array}{l}\text { Comparatively } \\
\text { costly }\end{array}$ & Potentially cheaper \\
\hline
\end{tabular}

can be used for low quality feedstock, which contains high FFAs.

\section{Current Technology in Biodiesel Production}

Currently, most of the biodiesel produced worldwide comes from the transesterification of vegetable oil, animal fats, and recycled greases through the addition of methanol (or other alcohols) and a catalyst, giving glycerol as a coproduct. These materials contain triglycerides, free fatty acids, and other contaminants depending on pretreatment process.

The most common catalysts in the production of biodiesel are homogeneous base catalysts such as sodium hydroxide and potassium hydroxide. The advantages of using homogeneous base catalyst is the reaction proceeds at a much higher rate and is less corrosive than the homogeneous acid $\left(\mathrm{H}_{2} \mathrm{SO}_{4}\right)$ catalyst. Typical catalyst loadings range from 0.3 $\%$ to about $1.5 \%$. After the reaction, the catalyst must be neutralized and wash with a lot of water to remove the salt produced [2,3].

The reaction is carried out using a batch, stirred tank reactor with operating temperature is usually about $65{ }^{\circ} \mathrm{C}$. Alcohol to triglyceride ratios from 4:1 to $20: 1$ (mole:mole) have been reported, with a $6: 1$ ratio most common. The main alcohol used in the production of biodiesel is methanol because of its low cost and availability [4].

Even though the homogeneous base catalyzed biodiesel production processes are relatively fast, and show high yield, they are still not very costcompetitive with petrodiesel ones because of the cost of raw material used and the catalyst cannot be recovered after the reaction. Choice of the fats or oils to be used in producing biodiesel depends on the process and raw material cost and impurities. Low quality oil contains high level of free fatty acid (FFA) and water. When FFA is present in the feedstock, it reacts with the homogeneous base catalysts and may deactivate the catalyst and form unwanted soap by-products. In addition, the present of water in the reaction mixture also leads to the deactivation of homogeneous catalysts. Ma and Hanna [2], reported that water should be kept below $0.06 \%$ and FFA should be kept below $0.5 \mathrm{wt}$ $\%$ to get the best conversions.

In order to reduce the production cost of biodiesel, some researchers conducted research by using solid catalyst and low quality oil such as residual oil from waste material [5]. Biodiesel production using solid catalysts has an economic benefit in terms of cheaper production costs because of reusable nature of the catalyst and the 
possibility to be use for low quality feedstock [6].

\section{Solid Catalyst}

A solid catalyst is a good alternative for homogeneous catalysts in the transesterification of vegetable oil for the production of biodiesel due to the fact that solid catalyst would not dissolve in the reactant mixture, thus eliminating the separation issues associated with the conventional homogeneous process. The removal of homogenous catalysts is technically difficult and large amount of wastewater is produced during the process and needs to be treated via neutralization process. Conventional homogeneous catalysts are expected to be replaced with solid catalyst due to economics and environmental reasons in the near future. Having said that, the research and development of solid bases catalyst in general has an upper hand than that of solid acids $[7,8]$.

\subsection{Solid bases catalyst for biodiesel production}

The development of basic solid catalysts for biodiesel production has been widely mentioned in the scientific journals which include the use of carbonates and hydro-carbonates of alkaline metals; alkaline metal oxides; alkaline metal hydroxides; anionic resins and basic zeolites. Solid bases catalyze reactions by donating electrons. Table 2 shows typical solid base catalysts used in biodiesel production. Some of these catalysts have shown good catalytic activity similar to those of homogeneous base catalysts. However, solid base catalysts are still far from an industrial application, due to the lack of technical and scientific knowledge pertaining to its behavior and most of the studies are based on small scale stirred batch reactors.

The performance of solid bases such as cesiumexchanged sodium zeolites (NaCsX), hydrotalcites $\left(\mathrm{Mg}_{6} \mathrm{Al}_{2}\left(\mathrm{CO}_{3}\right)(\mathrm{OH})_{16.4}\left(\mathrm{H}_{2} \mathrm{O}\right)\right)$, Barium hydroxide $\left(\mathrm{Ba}(\mathrm{OH})_{2}\right)$ and $\mathrm{MgO}$ have been investigated by Leclercq et al. [9]. They pointed out that strong basic properties are required to perform biodiesel synthesis reaction. Some of these solid catalysts such as alkali earth metal oxides $(\mathrm{CaO}, \mathrm{BaO})$ and alkali earth metal hydroxides $\left(\mathrm{Ca}(\mathrm{OH})_{2}, \mathrm{Ba}(\mathrm{OH})_{2}\right)$ are partially soluble in water and alcohol and present in the final biodiesel product. Results from Mazzochia et al. [10] confirmed that $\mathrm{Ba}(\mathrm{OH})_{2}$ is slightly soluble in the reaction mixture where the resulting biodiesel and glycerine contained $0.06 \%$ and $0.25 \%$ of barium, respectively.

Suppes et al. [11] carried out biodiesel production using zeolites namely $\mathrm{NaX}, \mathrm{NaY}$ faujasites, potassium-exchanged $\mathrm{NaX}$ (KX), cesium-exchanged $\mathrm{NaX}(\mathrm{CsX})$, and ETS-10 zeolite. The base strength of the metal ion exchanged zeolite increases with increasing electropositive nature of the cation. The occlusion of alkali metal oxide clusters in zeolite cages results in an increase in the basicity of these materials. Lotero et al. [12] reported that the use of ETS-10 zeolite has shown an $80 \%$ biodiesel conversion when conducted at $60{ }^{\circ} \mathrm{C}$ and after 24 hours of operation. They also reported leaching of ETS-10 into reaction mixture.

Helwani et al. [13] explained that alkaline earth oxides are potential solid bases for use in triglyceride transesterification. The origin of basic sites in alkaline earth oxides is generally believed to be generated by the presence of $\mathrm{M}^{2+}-\mathrm{O}^{2-}$ ion pairs in different coordination environments. The basic strength of the group II oxides and hydroxides increases by the following order; $\mathrm{Mg}<$ $\mathrm{Ca}<\mathrm{Sr}<\mathrm{Ba}$. Ca-derived bases are the most promising as they are cheaper and exhibit low methanol solubility. Gryglewicz [14] tested the performance of $\mathrm{CaO}, \mathrm{MgO}, \mathrm{Ca}(\mathrm{OH})_{2}$, and $\mathrm{Ba}(\mathrm{OH})_{2}$ for biodiesel production at the reaction temperature of $65^{\circ} \mathrm{C}$. Results showed that $\mathrm{Ba}(\mathrm{OH})_{2}$ exhibited good performance though it dissolved into methanol. It was also reported that $\mathrm{CaO}$ and $\mathrm{Ca}(\mathrm{OH})_{2}$ reacted with methanol to form calcium methoxide on the surface. These calcium methoxide ions catalysed the reaction similar to that of methoxide ions formed by $\mathrm{NaOH}$, but with low catalytic activity. On the other hand, it was established that $\mathrm{Ca}(\mathrm{OH})_{2}$ was unable to catalyze the reaction whilst $\mathrm{MgO}$ was found to be an inactive catalyst. The performance of $\mathrm{CaO}$ was $3 \sim 4$ times slower than that of $\mathrm{NaOH}$, giving $90 \%$ conversion in 2.5 hours. It has been reported that even if $\mathrm{CaO}$ is reused for several runs without any significant deactivation, dissolution of $\mathrm{CaO}$ does occur [15]. The catalytic reaction is resulted from the contribution of both heterogeneous and homogeneous catalysis in the formation of leached active species.

The catalytic activity of materials generated by loading alumina with alkali metal salts has also been investigated. Kim et al. [16] used $\mathrm{Na} / \mathrm{NaOH} / \mathrm{Y}^{-}$ $\mathrm{Al}_{2} \mathrm{O}_{3}$, a solid super-base, for the transesterification of vegetable oil to biodiesel. The catalyst was able to achieve equilibrium conversion of $94 \%$ in 2 hours. In spite of previously mentioned research efforts, there has been no successful commercial production of biodiesel using solid bases with main concerns are maintenance and reusability issues. 


\subsection{Solid Acids for biodiesel production}

Sulfuric acid and alkyl sulfonic compounds are probably the most extended acid catalysts used for the biodiesel production. These liquid acids may cause corrosion problem and consequent environmental hazards posed by them. For this reason and many others, such as the impossibility to reuse liquid acids, solid acid catalysts are preferred over liquid acid. Solid acid catalysts can replace strong liquid acids. However, the usage of solid acid catalysts for biodiesel production is still limited due to lack of understanding of the factors that govern the reactivity of solid acid catalysts. A variety of solid catalysts has been examined for the transesterification reaction and new catalysts continue to be reported in the literature. Table 2 shows some of the solid acids used in the biodiesel production.

Solid acids catalyze reaction either by donating protons or abstracting electrons. Solid acids are so well-developed that numerous solid acids are even stronger than sulphuric acid. They are called solid superacids. A superacid is defined as an acid that exhibits an acid strength higher than the acid strength of $100 \%$ sulphuric acid. Solid acids have been widely used in petroleum industry for applications like cracking and reforming. Table 3 shows some of the example of solid acid used in the study of biodiesel production. The solid acidcatalyzed process is clearly advantageous over liquid acid catalyst as it has the highest rate-ofreturn, and lowest capital investment, due to its simple process.

There are several considerations in the development of a strong solid acid; firstly, the catalyst should have higher stability of acid sites to avoid their leaching. Secondly is by enhancement of mass transfer to avoid diffusional limitations. In addition, it should be an inexpensive material that is readily available on the industrial scale. Considering these conditions, researchers searched for a strong Bronsted acid with an increased hydrophobicity and high thermal stability up to $250{ }^{\circ} \mathrm{C}$. Hydrophobic catalyst surfaces are preferable in biodiesel production to avoid the covering of the solid acid surface with water $[6,17]$.

Zeolites are among the different types of inorganic solids that have been employed as catalysts for the production of biodiesel. Since zeolites can be synthesized with variation of acidic and textural properties, it is possible to use zeolite catalyst in the biodiesel production. Recently mesoporous zeolites have shown promising results in biodiesel production using vegetable oil with high content of free fatty acids [18]. Noiroj et al. [19] reported the use of $\mathrm{KOH} / \mathrm{Na}-\mathrm{Y}$ zeolite catalysts to achieve a biodiesel yield of $91 \%$ conversion to methyl esters in 8 hours at $66{ }^{\circ} \mathrm{C}$. Microporous zeolites which have very small pore are not suitable for transesterification reaction of triglycerides because of the diffusion limitation of reactants inside micropores.

It appears that solid superacids are very useful catalyst in the biodiesel production. Sulfated zirconia and tungstated zirconia are typical examples of those superacids which show high catalytic performances. Furuta et al. [20] used tungstated zirconia-alumina, sulphated zirconiaalumina and sulphated tin oxide for their research on biodiesel conversion. The operation was conducted at $300{ }^{\circ} \mathrm{C}$ and the conversion yield was at $94 \%, 77 \%$ and $70 \%$ for soybean transesterification using tungstated zirconia-alumina, sulphated zirconia-alumina and sulphated tin oxide respectively. They also reported the conversion of $94 \%, 99 \%$ and $100 \%$ at operation temperature of $175{ }^{\circ} \mathrm{C}$ for the esterification of $\mathrm{n}$ octanoic acid (a representation of FFA) by using tungstated zirconia-alumina, sulphated zirconiaalumina and sulphated tin oxide respectively.

It was mentioned by Furuta et al. [21] that the catalytic effect for the esterification reaction is important for the production of biodiesel fuel due to the existence of free fatty acid in the low quality oil. Thus, the esterification of $n$-octanoic acid with methanol to methyl $n$-octanoate was carried out in the same manner as that of the transesterification of soybean oil. Tungstated zirconia-alumina, sulfated tin oxide and sulfated zirconia-alumina have shown high catalytic activities at temperature over $175{ }^{\circ} \mathrm{C}$ with no by-product detected. Furuta et al. [21] also reported that tungstated zirconia-alumina is a promising catalyst for the production of biodiesel fuels due to its superior catalytic activity for both transesterification and esterification.

Another important group of strongly solid acid catalysts used in biodiesel production through transesterification of triglycerides is that formed by supported heteropolyacids. Kulkarni et al. [23] reported that high catalytic activity in the transesterification of canola oil containing $10 \%$ of FFA was achieved by using immobilization of Keggin-type heteropolyacids (HPA) on different supports such as hydrous zirconia, silica, alumina and activated carbon. Biodiesel was also produced through simultaneous esterification and transesterification of a mixture of vegetable oil and free fatty acid with ethanol using heteropolyacids supported on diverse oxides.

Katada et al. [24] reported that a heteropoly acid-derived solid acid catalyst has shown higher catalytic activities for transesterification between triolein and ethanol as compared to the activities of 
conventional solid acid catalysts. The performance of the catalyst was sensitive to calcinations temperature and calcination temperature of about $500{ }^{\circ} \mathrm{C}$ provided a highly active catalyst.

\section{Potential of the Solid Acid Catalyst}

There are numerous publications on solid basecatalyzed transesterification with regards to their properties and catalytic activities. The solid base catalysts have shown high catalytic performance on high quality vegetable oils. On the contrary, poor catalytic performance is observed for low quality vegetable oils due to the presence of significant amounts of free fatty acids, which results in soap formation. An alternative way of processing these low quality vegetable oils is by using an acid catalyst. The drawback is that homogeneous acids such as hydrochloric acid and sulfuric acid need longer reaction time and may pose corrosion problem to the equipment. Table 3 lists some of research findings on biodiesel conversion using different solid acid catalyst. Findings show that acid-catalysed reaction needs high temperature and longer time for high yield of conversion.

Table 2. Typical solid acid and base catalysts employed for transesterification [31]

\begin{tabular}{|c|c|}
\hline Solid acid catalysts & Solid base catalysts \\
\hline Sulphonic ion exchanged & Hydrotalcites (Mg-Al) \\
\hline resin & Cs-exchanged sepiolite \\
\hline Amberlyst -15 & Oxides like $\mathrm{MgO}, \mathrm{CaO}$, \\
\hline Nafion & $\mathrm{La}_{2} \mathrm{O}_{3}, \mathrm{ZnO}$ \\
\hline Unstated Zironia-alumina & Quanidine anchored \\
\hline Sulphated tin oxide & cellulose/polymer \\
\hline Sulphated zirconia/alumina & NN'N" tricyclohexyl \\
\hline Zeolites (H-Y) H-Beta, H- & quanidine \\
\hline ZSM-5, ETS-4,10 & encapsulated in Y zeo- \\
\hline MCM family & lite \\
\hline Heteropoly acids & Metal salts of amino \\
\hline $\mathrm{H}_{3} \mathrm{PW}_{12} \mathrm{O}_{40}, \mathrm{H}_{4} \mathrm{SiW}_{12} \mathrm{O}_{40}$ & acids \\
\hline $\mathrm{Cs}_{2.5} \mathrm{H}_{0.5} \mathrm{PW}_{12} \mathrm{O}_{40}$ & $\mathrm{CaCO}_{3}, \mathrm{Ba}(\mathrm{OH})_{2}$ \\
\hline Zinc acetate on silica & Cs exchanged faujasites \\
\hline Organosulphonic acid on & Li-promoted $\mathrm{CaO}$ \\
\hline mesoporous silica & $\mathrm{KxX} / \mathrm{Al}_{2} \mathrm{O}_{3}(\mathrm{X}$ - halide \\
\hline Mesoporous unstated zirco- & ion or other \\
\hline \multirow[t]{2}{*}{ nium phosphate } & mono/di-valent anion) \\
\hline & Zinc aluminates \\
\hline
\end{tabular}

\section{Effect of Operating Conditions on the Biodiesel Production}

\subsection{Temperature of Reaction}

The rate of reaction is strongly influenced by the reaction temperature. Generally, the reaction is conducted at $65{ }^{\circ} \mathrm{C}$ and at atmospheric pressure. Transesterification can occur at different temperatures, depending on the oil used. Marchetti et al. [32] studied the effect of varying operating temperature on product yield using solid catalyst. The chosen reaction temperature was at $\mathrm{T}=30^{\circ} \mathrm{C}$, $45{ }^{\circ} \mathrm{C}$ and $55{ }^{\circ} \mathrm{C}$. It was found that increasing the operating temperature resulted in a rise in final conversion. Higher reaction rate is obtained at

Table 3. Lists of research findings on biodiesel production with different solid acid catalysts

\begin{tabular}{|c|c|c|c|c|}
\hline Solid Catalysts & $\begin{array}{l}\text { Conver- } \\
\text { sion (\%) }\end{array}$ & $\begin{array}{l}\text { Reaction } \\
\text { Condition } \\
\quad\left({ }^{\circ} \mathrm{C}\right)\end{array}$ & $\begin{array}{l}\text { Reac- } \\
\text { tion } \\
\text { Time } \\
(\mathrm{h})\end{array}$ & Ref. \\
\hline $\begin{array}{l}\text { Sulfated tin } \\
\text { oxide }\end{array}$ & 100 & \multirow{3}{*}{$175^{\circ} \mathrm{C}$} & \multirow{3}{*}{20} & \multirow{3}{*}{ [21] } \\
\hline $\begin{array}{l}\text { Sulfated zirco- } \\
\text { nia-alumina }\end{array}$ & 99 & & & \\
\hline $\begin{array}{l}\text { Zirconia- } \\
\text { alumina }\end{array}$ & 94 & & & \\
\hline Zinc oxide ( $\mathrm{ZnO})$ & 83 & \multirow[b]{2}{*}{$120^{\circ} \mathrm{C}$} & \multirow[b]{2}{*}{24} & \multirow[b]{2}{*}[22]{} \\
\hline $\begin{array}{l}\mathrm{H} \beta-\text { zeolite } \\
\text { Montmorillonite } \\
\mathrm{K}-10\end{array}$ & $\begin{array}{l}59 \\
47\end{array}$ & & & \\
\hline $\begin{array}{l}\text { Sulfated zirco- } \\
\text { nia } \\
\text { Sulfated stan- } \\
\text { nous oxide } \\
\text { Zinc oxide } \\
\mathrm{KNO}_{3} / \mathrm{ZrO}_{2} \\
\mathrm{KNO}_{3} / \mathrm{KL} \mathrm{zeo-} \\
\text { lite } \\
\text { Zirconia oxide }\end{array}$ & $\begin{array}{l}90.3 \\
90.2 \\
86.1 \\
74.4 \\
71.4 \\
64.5\end{array}$ & $200{ }^{\circ} \mathrm{C}$ & 4 & {$[25]$} \\
\hline $\begin{array}{l}\mathrm{Fe}-\mathrm{Co}^{-1} \\
\mathrm{Fe}-\mathrm{Zn}^{-1}\end{array}$ & $\begin{array}{l}32.8 \\
98.3\end{array}$ & $170^{\circ} \mathrm{C}$ & 8 & {$[26]$} \\
\hline $\begin{array}{l}\text { Tungstated zir- } \\
\text { conia-alumina }\end{array}$ & 90 & \multirow{3}{*}{$250^{\circ} \mathrm{C}$} & \multirow{3}{*}{20} & \multirow{3}{*}{ [27] } \\
\hline $\begin{array}{l}\text { Titanium zirco- } \\
\text { nia }\end{array}$ & 83 & & & \\
\hline $\begin{array}{l}\text { Aluminium zir- } \\
\text { conia }\end{array}$ & 80 & & & \\
\hline $\begin{array}{l}\mathrm{NaX} \text { zeolite } \\
\text { (Si/Al = } 1.23), \\
\text { loaded with } 10 \% \\
\mathrm{KOH}\end{array}$ & 85.6 & $65^{\circ} \mathrm{C}$ & 8 & {$[28]$} \\
\hline $\begin{array}{l}\text { Sulfonated car- } \\
\text { bon }\end{array}$ & 90 & $80{ }^{\circ} \mathrm{C}$ & 12 & [29] \\
\hline $\begin{array}{l}\text { Cesium ex- } \\
\text { changed tung- } \\
\text { stophosphoric } \\
\text { acid }\end{array}$ & 92 & $65^{\circ} \mathrm{C}$ & 3 & [30] \\
\hline
\end{tabular}


higher temperature, but operating the reaction close to methanol's boiling point could potentially lead to the formation of bubbles which in turn preventing the reaction on the three-phase interface (solid catalyst - oil - alcohol). Liu et al. [33] claimed that the optimum reaction temperature was obtained at $65{ }^{\circ} \mathrm{C}$ when using $\mathrm{CaO}$ as a solid catalyst. Similar finding was reported by Encinar et al. [34] in their study of trans-esterification reaction of triglycerides with methanol using $\mathrm{KNO}_{3} / \mathrm{CaO}$ catalyst.

\subsection{Ratio of Alcohol to Oil}

One of the most important variables affecting the yield biodiesel is the molar ratio of alcohol to triglyceride. The stoichiometric ratio for the transesterification requires three moles of alcohol and one mole of triglyceride to yield three moles of fatty acid ester and one mole of glycerol. However, transesterification is an equilibrium reaction in which a large excess alcohol is required to drive the reaction to the right. However, too high molar ratio of alcohol to vegetable oil causes an increase in the solubility of glycerol in methyl ester layer which makes the separation process difficult [35]. When glycerol remains in solution, it helps drive the equilibrium back to the left, lowering the yield of esters. Encinar et al. [34] conducted test runs based on different molar ratios of alcohol to vegetable oils using $\mathrm{KNO}_{3} / \mathrm{CaO}$ catalyst, namely; with different methanol/oil molar ratio of $6: 1,9: 1$ and 12:1. Higher methanol/oil molar ratio requires longer time for conversion. They claimed that the optimum methanol/oil molar ratio for the reaction is $6: 1$.

\subsection{Mixing Intensity}

In the transesterification reaction, mixing is very important since the reactants initially are a three-phase system. The reaction is diffusioncontrolled and poor diffusion between the phases results in a slow rate of reaction. Once the three phases are mixed and the reaction has started, stirring is no longer needed since methyl ester acts as a mutual solvent for the reactants [36]. Similarly Encinar et al. [34] reported that once the methyl ester is formed, they act as a mutual solvent for the reactants and eventually forming a single-phase system. The mixing effect is significant during the slow reaction rate region and the increase in mixing rate improves the mass transfer in the surface of the solid catalyst. As the single phase is established, mixing becomes insignificant. The understanding of the mixing effect on the kinetics of the transesterification process is important for the process scale-up design.

\subsection{Reaction Time}

The conversion of biodiesel increases with reaction time. Kim et al. [16] studied the biodiesel conversion yield using homogeneous catalyst $(\mathrm{NaOH})$ and heterogeneous catalyst $\left(\mathrm{Na} / \mathrm{NaOH} / \mathrm{Y}^{-}\right.$ $\mathrm{Al}_{2} \mathrm{O}_{3}$ ) with respect to their reaction time. The maximum biodiesel production was achieved within 1 hour of operation for both homogeneous and heterogeneous catalyst systems. However, the biodiesel yield for the homogeneous catalyst system was $20 \%$ higher than that of the heterogeneous catalyst system. Xie and $\mathrm{Li}$ [28] studied the effect of reaction time on the product yield in the presence of $35 \mathrm{wt} \% \mathrm{KI} / \mathrm{Al}_{2} \mathrm{O}_{3}$ catalyst. The reaction time was varied from 1 to 10 hours. The experiment results showed that the conversion increased steadily at reaction time of 4 to 8 hours, and then remained nearly constant thereafter. The maximum conversion of $90 \%$ of soybean oil was achieved after 8 hours [28].

\subsection{Ratio of catalyst to oil}

Biodiesel production can be affected by the amount of catalyst used in the reactions. For homogenous catalyst, biodiesel production is carried out using approximately $1 \mathrm{wt} \%$ catalyst. However, for heterogeneous catalyst the amount of catalyst used is depend on the type of solid catalyst. Liu et al. [37] studied the conversion of soybean oil to biodiesel using $\mathrm{CaO}$ as a solid catalyst. Biodiesel yield (95 \%) was obtained when reaction was carried out for $3 \mathrm{~h}$ using $8 \mathrm{wt} \%$ catalyst concentration. Garcia et al. [38] carried out a study using sulfated zirconia with catalyst concentration ranging from $2-5 \mathrm{wt} \%$. They reported the highest conversion was achieved if $5 \mathrm{wt} \%$ catalyst was used.

\section{Conclusions}

Several solid catalysts have been investigated for biodiesel synthesis but their uses have been limited to reasons associated with their reaction rates, unfavorable side reactions and leaching problem. Some solid catalyst has both acid and base property, thus enable to catalyze both esterification and transesterification reactions simultaneously. Further research and improvements are continuously being made for these catalysts in areas related to the stability of active sites, thermal stability and enhancement of mass transfer mechanisms. Studies are looking into improving the resistance to water impurities usually present in unrefined or low quality 
feedstock. It is expected that homogeneous catalysts will be replaced by solid catalysts mainly due to environmental and economic reasons.

\section{Acknowledgments}

The authors gratefully acknowledge the financial support provided by the Ministry of High Education under FRGS grant scheme.

\section{References}

[1] Hoydonckx, H.E., De Vos, D.E., Chavan, S.A. and Jacobs, P.A. (2004). Esterification and Transesterification of Renewable Chemicals: Catalytic Conversion of Renewables. Guest Editors: Herman van Bekkum and Pierre Gallezot. Topics in Catalysis. 27: 83-96).

[2] Ma, F. and Hanna, M.A. (1999). Biodiesel production: A review. Bioresource Technology. 70(1): 1-15.

[3] Freedman, B., Butterfield, R.O. and Pryde, E.H. (1986). Transesterification kinetics of soybean oil. Journal of the American Oil Chemists' Society. 63(10): 1376-1380.

[4] Zhang Y, Dube MA, McLean DD, Kates M. (2003) Biodiesel production from waste cooking oil: 1. Process design and technological assessment. Bioresource Technology. 89(1): 116.

[5] Mat R, Ling O.S, Johari A, Mohamed M. (2011) In situ biodiesel production from residual oil recovered from spent bleaching Earth. Bulletin of Chemical Reaction Engineering and Catalysis. 6(1): 53-57.

[6] López, D.E., Goodwin, J.J.G., Bruce, D.A. and Lotero, E. (2005). Transesterification of triacetin with methanol on solid acid and base catalysts. Applied Catalysis A: General. 295(2): 97-105.

[7] Hattori, H. (2001). Solid base catalysts: generation of basic sites and application to organic synthesis. Applied Catalysis A: General. 222(1-2): 247-259.

[8] Ono, Y. and Baba, T. (1997). Selective reactions over solid base catalysts. Catalysis Today. 38(3): 321-337.

[9] Leclercq, E., Finiels, A. and Moreau, C. (2001). Transesterification of rapeseed oil in the presence of basic zeolites and related solid catalysts. Journal of the American Oil Chemists' Society. 78(11): 1161-1165.

[10] Mazzocchia, C., Modica, G., Kaddouri, A. and Nannicini, R. (2004). Fatty acid methyl esters synthesis from triglycerides over heterogeneous catalysts in the presence of microwaves. Comptes Rendus Chimie. 7(6-7): 601-605.

[11] Suppes, G.J., Dasari, M.A., Doskocil, E.J.,
Mankidy, P.J. and Goff, M.J. (2004). Transesterification of soybean oil with zeolite and metal catalysts. Applied Catalysis A: General. 257: 213-223.

[12] Lotero, E., Goodwin Jr., J.G., Bruce, D.A., Suwannakarn, K., Liu, Y. and Lopez, D.E. (2006). The Catalysis of Biodiesel Synthesis. Catalysis. Royal Society of Chemistry. 19: 4183

[13] Helwani Z, Othman M.R, Aziz N, Kim J, Fernando W.J.N. (2009) Solid heterogeneous catalysts for transesterification of triglycerides with methanol: A review. Applied Catalysis A: General.363:1-10

[14] Gryglewicz, S. (1999). Rapeseed oil methyl esters preparation using heterogeneous catalysts. Bioresource Technology. 70: 249-253.

[15] Granados, M.L., Poves, M.D.Z., Alonso, D.M., Mariscal, R., Galisteo, F.C., Moreno-Tost, R., Santamaría, J. and Fierro, J.L.G. (2007). Biodiesel from sunflower oil by using activated calcium oxide. Applied Catalysis B: Environmental. 73(3-4): 317-326.

[16] Kim, H.J., Kang, B.S., Kim, M.J., Park, Y.M., Kim, D.K., Lee, J.S. and Lee, K.Y. (2004). Transesterification of vegetable oil to biodiesel using heterogeneous base catalyst. Catalysis Today. 93-95(1): 315-320.

[17] Lotero, E., Liu, Y., Lopez, D.E., Suwannakarn, K., Bruce, D.A. and Goodwin, J.G. (2005). Synthesis of Biodiesel via Acid Catalysis. Industrial \& Engineering Chemistry Research. 44(14): 5353-5363.

[18] Macario, A., Giordano, G., Onida, B., Cocina, D., Tagarelli, A., Giuffrẽ, A.M. (2010) Biodiesel production process by homogeneous/ heterogeneous catalytic system using an acidbase catalyst. Applied Catalysis A: General.378(2): 160-168.

[19] Noiroj, K., Intarapong. P., Luengnaruemitchai, A., Jai-In, S. (2009). A comparative study of $\mathrm{KOH} / \mathrm{Al}_{2} \mathrm{O}_{3}$ and $\mathrm{KOH} /$ $\mathrm{NaY}$ catalysts for biodiesel production via transesterification from palm oil. Renewable Energy. 34(4): 1145-1150.

[20] Furuta, S., Matsuhashi, H., and Arata, K. (2004). Biodiesel fuel production with solid superacid catalysis in fixed bed reactor under atmospheric pressure. Catalysis Communications. 5(12): 721-723.

[21] Furuta, S., Matsuhashi, H. and Arata, K. (2004). Catalytic action of sulfated tin oxide for etherification and esterification in comparison with sulfated zirconia. Applied Catalysis A: General. 269(1-2): 187-191.

[22] Karmee, S.K. and Chadha, A. (2005). Preparation of biodiesel from crude oil of Pongamia pinnata. Bioresource Technology. 96 
(13): 1425-1429.

[23] Kulkarni, M.G. and Dalai, A.K. (2006). Waste Cooking Oil An Economical Source for Biodiesel: A Review. Industrial \& Engineering Chemistry Research. 45(9): 2901-2913

[24] Katada, N., Hatanaka, T. Ota, M. Yamada, K. Okumura, K., Niwa, M. (2009). Biodiesel production using heteropoly acid-derived solid acid catalyst $\mathrm{H}_{4} \mathrm{PNbW}_{11} \mathrm{O}_{40} / \mathrm{WO}_{3}-\mathrm{Nb}_{2} \mathrm{O}_{5}$. Applied Catalysis A: General, 363: 164-168

[25] Jitputti, J., Kitiyanan, B., Rangsunvigit, P., Bunyakiat, K., Attanatho, L. and J envanitpanjakul, P. (2006). Transesterification of crude palm kernel oil and crude coconut oil by different solid catalysts. Chemical Engineering Journal. 116 (1): 61-66.

[26] Sreeprasanth, P.S., Srivastava, R., Srinivas, D. and Ratnasamy, P. (2006). Hydrophobic, solid acid catalysts for production of biofuels and lubricants. Applied Catalysis A: General. 314 (2): 148-159.

[27] Furuta, S., Matsuhashi, H. and Arata, K. (2006). Biodiesel fuel production with solid amorphous-zirconia catalysis in fixed bed reactor. Biomass and Bioenergy. 30(10): 870873.

[28] Xie, W., Li, H. (2006) Alumina-supported potassium iodide as a heterogeneous catalyst for biodiesel production from soybean oil. Journal of Molecular Catalysis A: Chemical. 255(1-2):1-9

[29] Chen, G., Fang, B. (2011). Preparation of solid acid catalyst from glucose starch mixture for biodiesel production. Bioresource Technology. 102(3): 2635-2640.

[30] Srilatha, K., Sree, R., Prabhavathi Devi. B.L.A, Sai Prasad P.S., Prasad R.B.N, Lingaiah N., (2012) Preparation of biodiesel from rice bran fatty acids catalyzed by heterogeneous cesium-exchanged 12-tungstophosphoric acids. Bioresource Technology. 116: 53-57.
[31] Kanakci, M. (2001). Production of Biodiesel from feedstocks with high free fatty acids and its effect on diesel engine performance and emissions. Ph.D Dissertation, Iowa State University, U.S.A

[32] Marchetti, J.M., Miguel, V.U., Errazu, A.F. (2007). Heterogeneous esterification of oil with high amount of free fatty acids. Fuel. 86 (5-6): 906-190.

[33] Liu, X., He, H., Wang, Y., Zhu, S., Piao, X. (2008). Transesterification of soybean oil to biodiesel using $\mathrm{CaO}$ as a solid base catalyst. Fuel. 87(2): 216-221.

[34] Encinar, J.M., GonzÃlez, J.F., Pardal, A., MartÃnez, G. (2010) Rape oil transesterification over heterogeneous catalysts. Fuel Processing Technology. 91(11): 1530-1536.

[35] Fillières, R., Benjelloun-Mlayah, B. and Delmas, M. (1995). Ethanolysis of rapeseed oil: Quantitation of ethyl esters, mono-, di-, and triglycerides and glycerol by highperformance size-exclusion chromatography. Journal of the American Oil Chemists' Society. 72(4): 427-432.

[36] Srivastava, A. and Prasad, R. (2000). Triglycerides-based diesel fuels. Renewable and Sustainable Energy Reviews. 4(2): 111133.

[37] Liu, X., He, H., Wang, Y., Zhu, S., Ziao, X. (2008). Transesterification of soybean oil to biodiesel using $\mathrm{CaO}$ as a solid base catalyst. Fuel 87: 216-221

[38] Garcia, C.M, Teixeira, S., Marciniuk, L.L. Schuchardt, U. (2008). Transesterification of soybean oil catalyzed by sulfated zirconia, Bioresources Technology 99: 6608-6613 